\title{
T1 mapping in daily CMR practice
}

\author{
Jonathan Nadjiri, Eva Hendrich, Albrecht Will, Cornelia Pankalla, Stefan Martinoff, Martin Hadamitzky
}

From 17th Annual SCMR Scientific Sessions

New Orleans, LA, USA. 16-19 January 2014

\section{Background}

Dual T1 mapping allows for a comprehensive assessment of myocardial tissue by combining detection of edema in the native scan and quantification of extracellular volume (ECV) after administration of Gadolinium. Recent studies proved the diagnostic value of T1 mapping in different pathologies; the aim of this study was, to evaluate the practicability and robustness of $\mathrm{T} 1 \mathrm{map}-$ ping in assessing common pathologies in daily CMR practice.

\section{Methods}

Since October 2012, we investigated 140 patients undergoing clinically indicated CMR examination by perfoming additional T1 mapping sequences which were not used for clinical diagnosis. We used a modified Short Modified Look Locker Inversion Recovery (ShMOLLI) sequence with 3 inversion pulses and a 4-(1)-3-(1)-2 readout pattern. The post Gadolinium scan for extra cellular volume calculation was performed $10 \mathrm{~min}$. after administration of a bolus of $0.2 \mathrm{mmol} / \mathrm{kg}$ body weight gadopentetate dimeglumine. Diagnosis was based on clinical information and standard sequences for assessment of myocardial tissue comprising native T2 weighted dark blood turbospin echo (tse) sequences, pre and early post gadolinium T1 weighted tse sequences and inversion recovery spoiled gradient echo sequences for late enhancement. Assessment of $\mathrm{T} 1$ relaxation time and ECV values was based on 3 short axis views and 1 long axis view using the AHA/ACC 17segment model.

\section{Results}

Native T1 relaxation time and ECV for the different pathologies are summarized in Table 1. For all pathologies either native T1 or ECV showed a significant difference when compared with healthy individuals. Particularly high native T1 values were observed in acute myocarditis, hypertrophic cardiomyopathy and amyoloidosis, a high ECV was found in myocardial infarction, sarcoidosis and amyoloidosis. Image quality was sometimes limited by incomplete motion correction, particularly in the long axis views and by partial volume effects in the apical short axis views.

\section{Conclusions}

T1 mapping and ECV correlated well with myocardial alterations in commonly diagnosed cardiac disorders.

Table $1 \mathrm{T1}$ relaxing times and ECV in patients collective

\begin{tabular}{ccccc}
\hline & T1 relaxing time \pm SD & p-value & ECV \pm SD & p-value \\
\hline Normal result: & $906 \mathrm{~ms} \pm 36 \mathrm{~ms}$ & reference & $25,5 \% \pm 2,7 \%$ & reference \\
\hline DCM: & $975 \mathrm{~ms} \pm 71 \mathrm{~ms}$ & $\mathrm{p}<0,001$ & $30,1 \% \pm 4,5 \%$ & $\mathrm{p}<0,001$ \\
\hline HCM: & $980 \mathrm{~ms} \pm 101 \mathrm{~ms}$ & $\mathrm{p}<0,001$ & $31,4 \% \pm 6,2 \%$ & $\mathrm{p}<0,001$ \\
\hline Acute myocardial infarction: & $973 \mathrm{~ms} \pm 61 \mathrm{~ms}$ & $\mathrm{p}<0,001$ & $39,9 \% \pm 8,6 \%$ & $\mathrm{p}<0,001$ \\
\hline Chronic myocardial infarction: & $934 \mathrm{~ms} \pm 131 \mathrm{~ms}$ & $\mathrm{p}=0,18$ & $39,4 \% \pm 11,9 \%$ & $\mathrm{p}<0,001$ \\
\hline Acute myocarditis: & $1017 \mathrm{~ms} \pm 59 \mathrm{~ms}$ & $\mathrm{p}<0,001$ & $38,2 \% \pm 8,9 \%$ & $\mathrm{p}<0,001$ \\
\hline Chronic myocarditis: & $955 \mathrm{~ms} \pm 45 \mathrm{~ms}$ & $\mathrm{p}<0,001$ & $27,9 \% \pm 5,1 \%$ & $\mathrm{p}=0,028$ \\
\hline Sarcoidosis: & $946 \mathrm{~ms} \pm 66 \mathrm{~ms}$ & $\mathrm{p}<0,001$ & $35,1 \% \pm 9,0 \%$ & $\mathrm{p}<0,001$ \\
\hline Amyloidosis: & $1078 \mathrm{~ms} \pm 54 \mathrm{~ms}$ & $\mathrm{p}<0,001$ & $58,1 \% \pm 10,4 \%$ & $\mathrm{p}<0,001$ \\
\hline
\end{tabular}

\footnotetext{
Department of Radiology and Nuclear Medicine, Deutsches Herzzentrum
} München, Munich, Bavaria, Germany 
It proved reliable and robust in daily clinical practice and allows for a good differentiation between normal findings and pcommon pathological CMR diagnoses. The combined use of native T1 and ECV quantification is promising approach for comprehensive assessment of the myocardium and may improve diagnostic accuracy of CMR in myocardial disease.

\section{Funding}

None.

Published: 16 January 2014

doi:10.1186/1532-429X-16-S1-P232

Cite this article as: Nadjiri et al: T1 mapping in daily CMR practice.

Journal of Cardiovascular Magnetic Resonance 2014 16(Suppl 1):P232.

Submit your next manuscript to BioMed Central and take full advantage of:

- Convenient online submission

- Thorough peer review

- No space constraints or color figure charges

- Immediate publication on acceptance

- Inclusion in PubMed, CAS, Scopus and Google Scholar

- Research which is freely available for redistribution

Submit your manuscript at www.biomedcentral.com/submit 